\title{
An Investigation of the Relationship between Oil Prices and Inflation in South Africa
}

\author{
Ferdinand Niyimbanira \\ Lecturer in Economics \\ Faculty of Management Sciences \\ Vaal University of Technology \\ Private bag X021, Vanderbijpark, 1900 \\ Email: ferdinandn@vut.ac.za
}

\section{Doi:10.5901/mjss.2013.v4n6p105}

\section{Abstract}

\begin{abstract}
It is widely believed that the increase in the real price of oil early 1970s was a major cause of high inflation and recession. In recent years, oil prices have been rising and its economic impact is an issue that continues to attract more attention globally and South Africa in particular. An increase in oil price and related goods causes a shift in the aggregate supply curve that results in higher price level. This paper uses Augmented Dickey-Fuller technique in testing the unit root property of the series, Johansen-Juselius Cointegration methods for testing long-run relationship between oil prices and inflation. The result showed that there is co-integrating relationship between oil price and inflation for South African data. Further effort was made to check the causality relationship that exists between the two variables by employing the Granger causality at two and four lag periods. The results showed the same at different lags. The first test was conducted using lag two (2) and in the result unidirectional causality was seen running from oil price to inflation. Further test at lag four (4) was carried out and it only supported the first by also indicating a unidirectional causality running from oil price to inflation. Policy implications and suggestion for future research are made in the paper.
\end{abstract}

Keywords: Inflation, Oil price, Cointegration, Granger Causality, Causality and South Africa

\section{Introduction}

Since World War II there were sharp increases in the oil price and for other related products. From 1960 to today, one may conclude that the World witnessed five important oil shocks: 1) in 1973-1974 when the Organisation of Petroleum Exporting Countries imposed embargo and greatly increase oil prices; 2) in 1978-1979 when Iranian revolution disrupt oil supplies; 3) in 1990s when Iraq invaded Kuwait, 4) in 1999 when price of barrel increased from $\$ 12$ to $\$ 24$ (Cunado \& Gracia, 2003) and 5) from 2010 to date due to Arab spring in north Africa and Middle-East.

As shown above, oil prices have been increasing and the issue of how it is affecting the economy, in general, and inflation in particular is becoming topical and widespread concern to many economists, politicians and media. Often, oil price and inflation are seen as being connected in a cause and effect relationship. However, much less agreement exists about the precise relationship between oil price and inflation rate, and the mechanism by which oil price affects inflation rate at macroeconomic level. From an empirical point of view, considerable research find that oil price shocks have affected inflation, for example, Hamilton (1983), (1988), (1996) and (2000); Tatom (1988); Mork (1989), (1994) and Hooker (1996) and (1999 a,b). Even though it is still debatable as to whether oil prices fluctuations are main causes of recession (Bohi, 1989), this paper considers that oil prices at least have effects on inflation. For Chen (2008) understanding the empirical linkage between oil prices and inflation rates is important as most monetary authorities attempt to keep inflation under control. Hence, finding the relationship between these two variables and to what extend it is will assist monetary authorities to conduct policy to accommodate these shocks.

In line with the above-mentioned, a large amount of theoretical and empirical research on this relationship for developed and developing countries since the first oil crisis of 1970s has been conducted, but few studies have focused on that of South Africa. The purpose of this study is therefore to econometrically examine the existence of the relationship between Oil prices and inflation in South Africa. This paper is organised as follows; section 1 is the introduction while section 2 is about literature review on oil price and inflation; section 3 outlines the econometric 
methodology for the analysis of data; in section 4 results and findings are discussed. Section 5 concludes the paper by summarising the major arguments and findings, while also providing some recommendations to policymakers.

\section{Relationship between Oil Prices and Inflation Theories}

Inflation is defined as a continuous increase in the general price level of an economy. According to Celik and Akgul (2011) inflation may be, firstly, a result of pressure of demand in an economy known as demand-pull inflation. In other words, this type of inflation is caused by excess demand bids up the prices of the limited output. For Van Rensburg et al. (2011) this type of inflation is about "too much spending chasing too few goods." Secondly, inflation may be a result of an initial increase in costs of production such as increase in real wages and salaries; and money prices of raw materials. Meaning the higher the cost of production, the smaller the production will be. This is known as cost-push inflation. If prices of raw materials (ie.oil) rise, firms decrease their supply of goods and services. Parkin et al $(2008$, p. 697) stated that "an increase in the price of oil accompanied by a decrease in availability of oil, can also decrease long-run aggregate supply." Thus, abrupt and unexpected rises in important resources such as oil sufficiently drive up overall production cost which will lead to higher prices later.

The oil prices and inflation are believed to be very connected in cause and effect in relationship. As oil prices move up or down, inflation follows in the same direction. The question to be asked is to what extend or how strong is the relationship between changes in oil prices and inflation. The reason of this is that; according to Langeger (2013) oil is a major input in the economy for example is used in providing public and private transportation, heating homes which affect most input costs and leads to an increase of costs of final products. For Tutor2u (2012) an increase in oil prices will cause aggregate supply to decrease in short-run which will put pressure on the price level, especially if a country is a large-scale importer of oil or/and has many industries that uses oil as an essential input in the production process. It should be highlighted that oil is regarded as final good in this paper. According to Celik and Akgul (2011) for a country which import oil, the positive or negative developments that occurring in the international market creates certain effects. This is not different from the case of South Africa. For example, in 2008; one of external shocks was the oil price increases which caused inflation to accelerate to 11.5 per cent.

Although, many studies such as Darby (1982); Hooker (1996); Cavallo (2008) and O'Brien and Weymes (2010) are done on this subject and their findings show that oil price has an important effect on inflation. However; this is challenged by Jackson (2005) who opined that "oil price hikes can no more cause inflation." According to him for inflation to take place one of the following things must happen: "1) the demand for money must fall, 2) the supply of money must rise or 3) 1 and 2 must occur together." This theory is in line with the one of Friedman who believed that to prevent inflation; the money supply should be increased at the same level economic growth is. It should be added that inflation, according to rational expectation theory may be a consequence of the economic policies applied by government because individuals are rational being who may not make mistakes (Celik \& Akgul, 2011).

But, the negative correlation between oil price and real output seems to have been accepted as a fact that leads to high inflation (Mork et al, 1994). According to Hamilton's (1983) article using the United States of America data, exogenous shocks to oil prices have significant effects on real economic activities. This also has been confirmed by different studies such as Mory (1993), Mork (1994) and Hooker (1996) inducing that oil prices increases reduces real output while oil prices declines has no effect, also when testing causality oil prices has Granger causes but no macroeconomic variables including inflation Granger cause oil prices in the later period.

\section{Econometric Methodology}

This paper follows the methodology used by Chimobi (2010) published in Journal of Sustainable Development and Niyimbanira's (2013) one, by employing an econometric model to achieve the empirical findings. Firstly, this paper investigates the short-run and long-run relationship between oil price and inflation by applying Johansen (1988) cointegration test and error correction model (ECM). Secondly, the study applies the Granger causality test to determine the direction of causality between the two variables.

\subsection{Model Specification}

The followings are mathematical and econometric models showing the relationship between inflation and oil price: $I N F=f\left(P_{O}\right)$ 


$$
I N F=\alpha_{0}+\alpha_{1} P_{O}+\varepsilon_{t}
$$

Where

INF stands for inflation and $P_{0}$ stands for oil Price; while $\alpha_{0}$ is the intercept; $\boldsymbol{\varepsilon}$ the random error tem and $\boldsymbol{t}$ stands for time trend.

\subsection{Data Description and Sources}

To examine the relationship between oil price and inflation, oil price data were collected from Mundilndex; while Inflation is proxied by core inflation collected from statistics South Africa website. The reason why this paper uses core inflation not consumer price index or percentage change in it is that "in their efforts to secure a low and stable inflation environment, therefore limit the impact of inflationary pressure emanating from rising oil prices, monetary policymakers pay close attention to core inflation for several reasons. One is that the exclusion of the volatile food and energy components makes it a more reliable indicator of the underlying trend in inflation. Fluctuations in the prices of food and energy may reflect exogenous shocks, that is, developments that are not inherent to the dynamics of the economy..." (Cavallo, 2008, p. 25). In addition; formal evidence provided by Blinder and Reis (2005) shows that core inflation predicts future overall inflation better than overall inflation itself.

\subsection{Estimation Technique}

\subsubsection{Checking for Stationarity}

According to Niyimbanira (2013) when analysing time series data, it is very crucial to use unit root test to check if these time series are stationary or non-stationary. The main importance of this test is that it helps to avoid the problem of spurious regression. For Harris (1995, p. 27) "if a variable contains a unit root then it is non-stationary and unless it combines with other non-stationary series to form a stationary cointegration relationship, then regression involving the series can falsely imply the existence of a meaningful economic relationship." One of the most popular tests to detect issue of stationarity and non-stationarity is Augmented Dickey-Fuller (ADF) which was initiated by Dickey and Fuller $(1979,1981)$. According to Chomobi (2010) "Augmented Dickey-Fuller test relies on rejecting a null hypothesis of unit root (the series are non-stationary) in favor of the alternative hypotheses of stationarity. The tests are conducted with and without a deterministic trend (t) for each of the series." Hence; ADF equation is as follows:

$$
\Delta y_{t}=\beta_{1}+\beta_{2} t+\delta y_{t-1}+\alpha_{i} \sum_{i=1}^{m} \Delta y_{t-1}+\varepsilon
$$

Where $\Delta y_{t}=\left(y_{t-1}-y_{t-2}, \Delta y_{t}=\left(y_{t-2}-y_{t-3}\right)\right.$ and so on and $\varepsilon$ is the white noise term, while $m$ for the lag length. The ADF test is comparable to the simple DF test, but the slight difference is that the first involves adding an unknown number of lagged first differences of the dependent variable to capture autocorrelation in omitted variables that would otherwise enter the error term.

\subsubsection{Testing for Cointegration}

This is the second step this paper uses. In general, according to Dougherty (2011, p.504) "a linear combination of two or more time series will be non-stationary if one or more of them is non-stationary, and the degree of integration of the combination will be equal to that of the most highly integrated individual series." Harris (1995, p.22) describes this theory by saying that "if a series must be differenced $d$ times before it becomes stationary, then it contains $d$ unit roots and is said to be integrated of order $d$, denoted $I(d)$." For Dickey and Fuller (1981) a lack of cointegration means that the longrun relationship between variables in equation does not exist. Therefore, to test the long-run relationship between petrol price and inflation in South Africa, a Johansen-Jeselius maximum likelihood cointegration analysis was performed. There are two types of Johansen test, either with trace or with eigenvalue, and the inferences might be a little bit different. The null hypothesis for the trace test is the number of cointegration vectors $r \leq$ ?, the null hypothesis for the eigenvalue test is $r=$ ?. Just like a unit root test, there can be a constant term, a trend term, both, or neither in the model.

As said above, this paper follow Chimobi (2010) where Johansen's methodology takes its starting point in the Vector Autoregression (VAR) of order $\mathrm{P}$ given by:

$$
y_{t}=\mu+\Delta_{1} y_{t-1}+--+\Delta p y_{t-p}+\varepsilon_{t}
$$



innovations.

Where $y_{t}$ is an $n \times 1$ vector of variables that are integrated of order commonly denoted (1) and $\varepsilon$ is an $n \times 1$ vector of

\subsubsection{Granger Causality Test}

Granger (1969) proposed a time-series data based approach in order to determine causality. In the Granger-sense $\mathrm{x}$ is a cause of $y$ if it is useful in forecasting $y 1$. In this framework "useful" means that $x$ is able to increase the accuracy of the prediction of $y$ with respect to a forecast, considering only past values of $y$. After cointegration test for a long-run relationship, we test for causality between oil price and Inflation in South Africa. Chimobi (2010, p.162) emphasised that "if the two variables are co-integrated, an Error Correction term (ECT) is required to be included in the following bivariate autoregression:

$$
\begin{aligned}
& I N F_{t}=\alpha_{0}+\sum_{i=1}^{n} \alpha_{1 t} I N F_{t-1}+\sum_{i=1}^{m} \alpha_{2 t} P_{o t-1}+\delta_{1} E_{t-1}+\varepsilon_{1 t} \\
& P_{O t}=\beta_{0}+\sum_{i=1}^{m} \beta_{1 t} I N F_{t-1}+\sum_{i=1}^{n} \beta_{2 t} P_{o t-1}+\delta_{1} E C T_{t-1}+\varepsilon_{1 t} \ldots \ldots . .
\end{aligned}
$$

Where INF is the core inflation and Po is oil prices. The term ECTt-1 is the error correction term derived from the long-run cointegrating relationship in equation 4 . It should be noted that the estimate $\delta 1$ and $\delta 2$ can be interpreted as the speed of adjustment. However, equation 5 and 6 would become 7 and 8 respectively if long run relationship between inflation and oil price does not exist. In other words, the term ECT will be removed and bevariate autoregression equation 5 and 6 become:

$$
\begin{aligned}
& I N F_{t}=\alpha_{0}+\sum_{i=1}^{n} \alpha_{1 t} I N F_{t-1}+\sum_{i=1}^{m} \alpha_{2 t} P_{o t-1}+\varepsilon_{1 t} \\
& P_{O t}=\beta_{0}+\sum_{i=1}^{m} \beta_{1 t} I N F_{t-1}+\sum_{i=1}^{n} \beta_{2 t} P_{O t-1}+\varepsilon_{1 t}
\end{aligned}
$$

\section{Empirical Results and Discussion}

\subsection{Unit root test at Levels}

As mentioned in the section of methodology, unit root test is about testing for stationary of the individuals variables using Augmented Dicker Fuller (ADF). To estimate the relationship this paper is investigating, Eviews software version 6 is used. The results for unit root test are show that the calculated absolute t-statistic is less than the absolute value of the critical value. This also is confirmed with $p$ values which are all greater than all levels. Therefore, the null hypothesis of individual variables being non stationary is accepted that oil price and inflation are not stationary at all levels. In other words, there is enough evidence to conclude that both inflation and oil price have unit root. The results for unit root test are shown in Table 1.a and 1.b bellows:

Table 1.a. ADF Stationary Test at level (Oil Price)

\begin{tabular}{lccc}
\hline \hline & & t-Statistic & Prob. $^{*}$ \\
\hline \hline \multicolumn{2}{l}{ Augmented Dickey-Fuller test statistic } & -2.314138 & 0.1698 \\
\hline & Test critical values: & -3.503049 & \\
& 5\% level & -2.893230 & \\
& $10 \%$ level & -2.583740 & \\
\hline \hline
\end{tabular}

Table 1.b. ADF Stationary Test at level (Inflation)

\begin{tabular}{lccc}
\hline \hline & & t-Statistic & Prob. $^{*}$ \\
\hline \hline & & & \\
Augmented Dickey-Fuller test statistic & 0.770965 & 0.9930 \\
\hline Test critical values: & 1\% level & -3.506484 & \\
& 5\% level & -2.894716 & \\
& 10\% level & -2.584529 & \\
\hline \hline
\end{tabular}




\subsection{Unit Root Test at First Difference}

Following above result, both variables were differenced once and the ADF test was conducted on them as shown in Table 2.a and 2.b. The coefficients compared with critical values at $1 \%, 5 \%$ and $10 \%$ show that variables were stationary at first difference. Meaning, statistical evidence concludes that oil price and inflation become stationary in their first differences. Therefore, the null hypothesis of non stationary is rejected implying that the variables are integrated of order one.

Table 2. a. ADF Stationary at First Difference (Oil Price)

\begin{tabular}{lccc}
\cline { 2 - 3 } & & & \\
\hline \hline & & & \\
\hline & -Statistic & Prob. $^{*}$ \\
\hline Tugmented Dickey-Fuller test statistic & -3.724098 & 0.0052 \\
& 1\% level critical values: & -3.501445 & \\
& 5\% level & -2.892536 & \\
& 10\% level & -2.583371 & \\
\hline \hline
\end{tabular}

*MacKinnon (1996) one-sided p-values.

Table 2. a ADF Stationary at First Difference (Inflation)

\begin{tabular}{lccc}
\cline { 2 - 3 } & & & \\
\hline \hline & -Statistic & Prob. $^{*}$ \\
\hline Augmented Dickey-Fuller test statistic & -4.382708 & 0.0006 \\
\hline Test critical values: & 1\% level & -3.506484 & \\
& 5\% level & -2.894716 & \\
& $10 \%$ level & -2.584529 & \\
\hline \hline
\end{tabular}

${ }^{\star}$ MacKinnon (1996) one-sided p-values.

\subsection{Testing for Cointegration}

Using methodology proposed by Johansen and Juselius (1990), the result of cointegration condition which test the existence of long run relationship between variables in question (inflation and oil price in this case) are presented in table 3. a (Trace Statistics) and 3.b (Maximum Eigenvalue). The results reveal that all variables in the model, despite initially being individually non stationary, are cointegrated. This leads to the conclusion that the long run relationship between oil price and inflation does exist in South Africa. Therefore, there is a need to further subject the variables to error correction test which helps to estimate how the observed model moves toward the long run equilibrium whenever it has been pushed away (Engle and Granger, 1987).

Table 4.a Unrestricted Cointegration Rank Test (Trace)

\begin{tabular}{lcccc}
\hline \hline $\begin{array}{l}\text { Hypothesized } \\
\text { No. of CE(s) }\end{array}$ & Eigenvalue & Trace & 0.05 & \\
\hline \hline None ${ }^{*}$ & 0.207361 & Statistic & Critical Value & Prob. $^{* *}$ \\
At most 1 & 0.011621 & 21.23462 & 15.49471 & 0.0061 \\
\hline \hline
\end{tabular}

Trace test indicates 1 cointegrating eqn(s) at the 0.05 level

* denotes rejection of the hypothesis at the 0.05 level

**MacKinnon-Haug-Michelis (1999) p-values

Table 4.b Unrestricted Cointegration Rank Test (Maximum Eigenvalue)

\begin{tabular}{lcllc}
\hline \hline Hypothesized & & Max-Eigen & 0.05 & \\
No. of CE(s) & Eigenvalue & Statistic & Critical Value & Prob. $^{* *}$ \\
\hline \hline None ${ }^{*}$ & 0.207361 & 20.21771 & 14.26460 & 0.0051 \\
At most 1 & 0.011621 & 1.016911 & 3.841466 & 0.3133 \\
\hline \hline
\end{tabular}

Max-eigenvalue test indicates 1 cointegrating eqn(s) at the 0.05 level

* denotes rejection of the hypothesis at the 0.05 level

**MacKinnon-Haug-Michelis (1999) p-values 


\subsection{Vector Error Correction Estimates}

A multivariate vector error correction model (VECM) is estimated which appears as an error correction term, is significant in the South African oil price and inflation. The results show that the system corrects its last period of disequilibrium (i.e. the speed of adjustment to restore equilibrium in the dynamic model) by more $10 \%$ a year and a level of adjustment is statistically significant as indicated in the table 5 below.

Table 5: VEC Results

\begin{tabular}{lc} 
Cointegrating Eq: & CointEq1 \\
\hline \hline DIF_INF(-1) & 1.000000 \\
DIF_OIL(-1) & 13.18965 \\
& $(3.75801)$ \\
& {$[3.50974]$} \\
C & -1.267152
\end{tabular}

\subsection{Model consolidation Test and the Overall Goodness of Fit}

The overall goodness of fit of the model can be analyzed by seeing the coefficient of determination or the value of $R$ square and $\mathrm{R}$ square adjusted for the degrees of freedom. The $\mathrm{R}$ squared value of the model was 0.8992 which means that $89.92 \%$ of variation in the dependent variable that is inflation is caused by variation in the independent variable which is oil price in this case. The adjusted $\mathrm{R}$ square value confirms this result.

To test also overall goodness of fit, one also need to check for heteroskedasticity, this generally means that the variance of the error term is not constant over time. In other words the independent variables are affected by the variation in error term. The results in table 6 below show that heteroskedasticity does not exist in the model as the probability of chi square came out to be greater than 0.05 (0.3985 in this case).

Table 5. VEC Residual Heteroskedasticity Tests: No Cross Terms (only levels and squares)

Joint test:

\begin{tabular}{ccc}
\hline \hline Chi-sq & df & Prob. \\
\hline \hline 92.81323 & 90 & 0.3985 \\
\hline \hline
\end{tabular}

\subsection{Granger Causality Test Analysis}

According to Chimobi (2010) "causality does not necessarily suggest exogeneity in the sense that the result gotten may not explain whether the relationship is positive or negative." However, it is widely believed by many scholars and economists that inflation and oil price are positively related. In other words, if oil price increases inflation will also increase. In any case the following result shown in the tables below reveals the direction of causality between inflation and oil price lag two (2). Following the result in the table 7, the null hypothesis that Dif_Oil Price does not Granger Cause Dif_INF is rejected and it is safe to conclude that Uni-directional causality run from oil price to inflation at lag two (2). This was confirmed by the results obtained by rejecting the same null hypothesis at lag 4 .

Table 7. Pairewise Granger Causality Tests (2)

\begin{tabular}{lccc}
\hline \hline Null Hypothesis: & Obs & F-Statistic & Prob. \\
\hline \hline DIF_OIL PRICE does not Granger Cause DIF_INF & 93 & 24.2641 & $4 . E-09$ \\
DIF_INF does not Granger Cause DIF_OIL PRICE & & 0.17583 & 0.8391 \\
\hline \hline
\end{tabular}




\section{Conclusion}

The purpose of this study was to find out the existence of the relationship between oil price and inflation in South Africa. The methodology employed was the cointegration and Granger causality test. This paper uses the Johansen-Juselius cointegration test which has been proven to be superior to the Engle Granger one in assessing the cointegrating properties of variables. A stationarity test was carried out using Augmented Dickey-Fuller (ADF) test. The variables were found to be stationary at first difference which mean they were integrated of order one. The results from cointegration test support the presence of a long-run relationship between oil price and inflation in South Africa and are in consistent with research conducted in other countries. Beside the confirmation of the existence of cointegration between oil price and inflation, further effort was made to check the causality and it was found that oil price does cause inflation. For future research, other variables need to be included in the model because this paper used only one explanatory variable (oil price) which is one of determinants of inflation. The findings of this paper would suggest that monetary authorities in South Africa when attempt to keep inflation under control, they should also take oil price in consideration.

\section{References}

Bohi, D.R. (1989). Energy Price Shocks and Macroeconomics Performance. Resource for Future, Washington DC.

Cavallo, M. (2008). Oil Prices and Inflation. Available at http://www.frbsf.org/publications/economics/letter/2008 Accessed on 21 April.

Celik, T. and Akgul, B. (2011). Changes in Fuel Prices in Turkey: An Estimation of the Inflation Effect Using VAR Analysis. Journal of Economic and Business, 14(2), 11-21.

Chen, S. S. (2008). Oilprice Pass-Through into Inflation. Energy Economic, 31, 126-133.

Chimobi, O. P. (2010). Inflation and Economic Growth in Nigeria. Journal of Sustainable Development, 3(2), 159-166.

Cunado, J. \& Perez de Gracia, F. (2003). Do oil Price Shocks Matter? Evidence for Some European Countries. Energy Economics, 25, 137-154.

Darby, M. R. (1982).The Price of Oil and World Inflation and Recession. The American Economic Review, 72(4), 738-751.

Dougherty, C. (2011). Introduction to Econometrics. 4th Ed., Oxford University Press.

Engle, R. W., \& Granger, C.W.J. (1987). Cointegration and Error Correction: Representation, Estimation and Testing, Econometrica, 55(2): 251-276.

Granger, C. W. J. (1969). Investigating Causal Relations by Econometric Models and Cross-spectral Methods. Econometrica, 37 (3), pp. 424-438.

Hamilton, J. (1988). A Neoclassical Model of Unemployment and the Business Cycle. Journal of Political Economy, 96, 593-617.

Hamilton, J. (1996). This is what Happened to the Oil Price-Macroeconomy Relationship. Journal of Monetary Economics, 38, 215-220.

Hamilton, J., (1998). Crude oil prices and US economic performance: Where does the asymmetry reside? Energy Journal, 19, 107-132.

Hamilton, J., (2000). What is an oil shock? NBER working paper, no. 7755.

Harris, R. (1995). Using Cointegration Analysis in Econometric Modelling. London, Prentice Hall//Harvester Wheatsheaf.

Hooker, M. (1996). What happened to the oil price-macroeconomy relationship? Journal of Monetary Economics, 38, 195-213.

Hooker. M., (1999a). Are oil shocks inflationary? Asymmetric and nonlinear specifications versus change in regime. Federal Reserve Board, mimeo.

Hooker. M., (1999b). Oil and the macroeconomy revisited. Federal Reserve Board, mimeo

Jackson, G. (2005). Oil Prices and the Inflation Myth. Available at http://www.brookesnews.com/051010oil.html accessed on 20 April.

Johansen, S., \&. Jeselius, K . (1990). Maximum Likelihood Estimation and Inference on Cointegration with Application to the Demand for Money. Oxford. Bulletin Acon. Stat., 52(2):169-210.

Lengager, C. (2013). What is the relationship between oil prices and inflation? Available at http://www.investopedia.com/ask/answers/06/oilpricesinflation.asp. Accessed on 20 April.

Mork, K. (1989). Oil and the macroeconomy when prices go up and down: an extension of Hamilton's results. Journal of Political Economy, 97, 740-744.

Mork, K. (1994). Business Cycles and the Oil Market. Energy Journal, 15, 15-38.

Mork, K. Olsen, O. \& Mysen H. T. (1994). Macroeconomic responses to oil price increases and decreases in seven OECD countries. Energy Journal, 15(4), 19-35.

Mory, J. F. (1993). Oil Prices and Economic Activity: Is the Relationship Symmetric? Energy Journal, 14(4), 151-161.

Niyimbanira, F. (2013, March). An Overview of Methods for Testing Short- and Long-Equilibrium with Time Series Data: Cointegration and Error Correction Mechanism. Mediterranean Journal of Social Sciences , 4(4), 151-156.

O'brian, D. \& Weymes, L. (2010). The Impact of Oil Prices on Irish Inflation. Quarterly Bulletin 03.

Parkin, M., Powell, M. \& Matthews, K. (2008). Economics. 7th Ed. London, Pearson.

Tatom, J., (1988). Are the Macroeconomic Effects of Oil Price Changes Symmetric? Carnegie-Rochester Conference Series on Public Policy 14, 325-368.

Tutor2u (2010). Inflation and Oil Prices. Available at www.tutor2u.net/economics/topics/inflation/oli_prices.htm accessed on 20 April. 
